\title{
Performance Model of Kulcapi (Karo Musical Instrument) as a Teaching Material in Guitar Learning
}

\author{
Panji Suroso $^{1}$, Adina Sastra Sembiring ${ }^{1}$, Uyuni Widiastuti ${ }^{1}$, \\ Muklis Hasbullah', Bakhrul Khair Amal ${ }^{2}$ \\ ${ }^{1}$ Lecturer at Faculty of Languages and Arts, State University of Medan, Indonesia \\ ${ }^{2}$ Lecturer in Social Science Faculty, State University of Medan, Indonesia \\ b4khrul.4m4l@gmail.com
}

\begin{abstract}
This study examines performance model of Kulcapi Karo as a teaching material in guitar learning classes at Music Art Study Program in Unimed. To obtain maximum learning outcomes in the learning process, creative strategies and methods are created in utilizing local music culture as a capital in improving music playing skills. Efforts are made in various ways to maximize learning by reviewing and analyzing matters related to the learning process such as; analyze learning objectives, teaching material, strategies or learning methods, including local cultural material as a learning resource that can be adapted to the development and needs of the community in the world of education that continues to grow. Based on this, it is very important if Kulcapi's musical instrument culture as local culture can be packaged and used as teaching material in learning guitar music instruments. This is intended to further enrich students' understanding of theoretical concepts and the practice of playing stringed musical instruments is not only limited to popular knowledge, but also on things that are more specifically including traditional ones. With the effort to study and understand the Kulcapi instrument as teaching material, students must absolutely understand the organology structure and the technique of playing Kulcapi to be able to be developed to the level of being able to play better musical instruments. The technique of playing Kulcapi instrument as a capital in developing students' abilities in guitar courses seems to be more able to improve the achievement of better quality learning outcomes.
\end{abstract}

Keywords: model; learning; Kulcapi

\section{Introduction}

The learning process on campus is an interaction event involving students, educators by implementing curriculum designs that are applied to the achievement of the acquisition of knowledge, mastery of certain skills, and the formation of good attitudes and self-confidence in students. The learning process is expected to continue to be able to develop and be able to produce innovative learning products that are able to compete and be able to answer challenges and be able to meet educational needs in the community.

To obtain maximum learning outcomes in the learning process it is necessary to do creative and innovative efforts by the teaching staff. These efforts can be carried out in various ways, including the activities of analyzing and updating learning devices, such as; methods, techniques and provision of teaching materials or learning media as well as periodic reviews of the curriculum so that they can be adapted to the development and needs of the community in the ever-expanding world of education.

Ethnic Karo in North Sumatra have a culture playing stringed instruments called Kulcapi. In organology, Kulcapi has a shape construction that can function almost the same as a guitar. As a tradition, the technique of playing Kulcapi is only learned from generation to generation by a small part of the Karo community. Based on information from traditional 
music experts, the Kulcapi instrument is very organologically closely related to the legend of the Karo folklore in Kesain Kuta, as in the story of the legend of the village of Tarigan, and the legend of the sitajor horse proponent. the karo community.

Based on this, it is considered very important if the culture plays the Kulcapi instrument can be packaged and used as teaching material learning guitar instruments in Unimed music education. This is so that the guitar learning process can further enrich students' understanding of the theoretical concepts of traditional stringed music instruments in North Sumatra. With the effort to study and understand Kulcapi's instrument on this guitar course, it will further refine the teaching material in order to achieve better quality learning outcomes. Based on the background above, the problem can be formulated as follows; How to apply the kulcapi game model to guitar learning and whether applying the game model can improve students' ability to play guitar. This issue will be the main focus of this study.

\section{Review of Literature}

This study uses a qualitative approach by following the opinions of Miles and Huberman (1984), namely (1) data collection (data collector), which is carried out through interviews, observations, digest documents, recording and recording; (2) data reduction (data reduction), which is done by summarizing, selecting the main things, focusing on the important things, looking for themes and patterns and discarding unnecessary ones; (3) data display (data presentation), which is done by showing data and presenting it in the form of narrative texts and charts; (4) conclusion drawing / verification (conclusions / verification) carried out by drawing conclusions and verification of the research findings. This opinion of Miles and Huberman is then explored to determine the steps specified in the implementation of this research. These steps include the following:

1) Research preparation phase which includes designing proposals, conducting literature studies, determining research topics, formulating problems and research objectives, determining the location of research, and establishing research methods.

2) Phase of collecting primary data and secondary data. Primary data is obtained through in-depth interviews and participant observation aimed at data collection.

3) The phase of data analysis is done by categorizing and analyzing primary and secondary data, conducting discussions with experts.

4) Stage Formulate a learning model.

5) The stage of applying the formulation of the learning model of kulcapi in playing the guitar.

6) Stage of conducting learning assessment.

7) The stage of concluding the results of the study.

\section{Result and Discussion}

In designing Kulcapi's model performance as a subject matter in guitar learning for students In Music Study Programs who take elective subjects for stringed musical instruments an analysis of the related subjects is included: Analyzing learning needs and objectives, analysis of preparation and preparation of learning material, analysis of strategies for implementing learning and evaluating learning outcomes. In addition, an analysis of the 
physical instruments which will be used as learning material was also carried out. In analyzing it, a study of the organology of Kulcapi instrument was conducted and the technical techniques to be formulated as learning instruments for musical instruments.

\subsection{Organology Analysis and Kulcapi Model Perfomance}

In discussing the organological theory concept in question, we will see a number of organological theory conceptions presented by several experts, including the concept proposed by Mantle Hood (1982: 124) that the organological problem has a tendency to be a limitation in describing physical appearance, acoustic property and history of musical instruments. Furthermore, organology is the science of musical instruments, which not only covers the history and description of musical instruments, but as important as 'science' from the instrument itself, among others: performance techniques, musical functions, decorative, and variations of social culture.

In addition to the above opinion that the study of organology or cultural material music in ethnomusicology has also been proposed by Allan P Merriam (1964) as follows: that the study area includes studies of musical instruments compiled by researchers with the classification commonly used, namely: idiophones, membranofones, aerophones, and chordophones. Besides that, every musical instrument must be measured, described, and drawn on a scale or photographed; principles of manufacture, materials used, motifs of decoration, methods and techniques of performances, determining the notes produced, and theoretical problems need to be noted. In addition to the problem of musical instrument descriptions, there are still a number of other analytical problems that can be the target of ethnomusicology field research, including the usefulness and social functions of the supporting community.

\section{- Kulcapi Instrument Organology}

In classifying the Kulcapi instrument, researchers refer to the theory proposed by Curt Sach and Hornbostel (1961), namely: "The music classifier system is based on the main vibrating source. This classification system is divided into four parts, namely: Idiophones, (the main vibrator is the body of the instrument itself), Aerophones, (the main vibrator is air), Membranophones, (the main vibrator is the skin or membrane), Kordofon (the main vibrator sounds is a string or string). Referring to the theory, kulcapi is classified as a musical instrument because the string is the main source of vibrating sound originating from the line. In accordance with its shape, kulcapi is a musical instrument that has a neck (neck) and the strings are parallel to the resonator box, in which the more detailed ones are categorized as two-strenged fretted-necked lute.

\section{- Construction of Kulcapi's Parts}

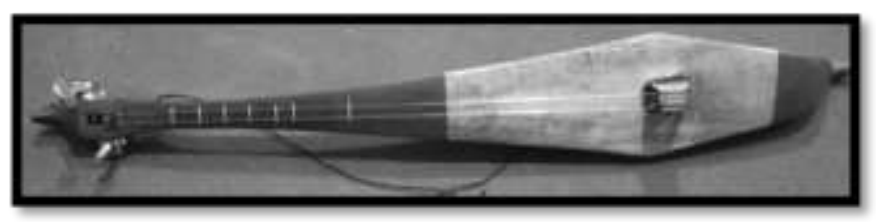

Next is the Kulcapi Instrument based on instrument parts

1) Head of Head Or Upper Part of Head 


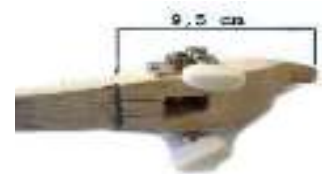

2) Kulcapi’s Neck

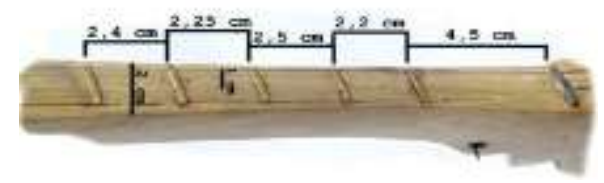

3) Resonator Cover

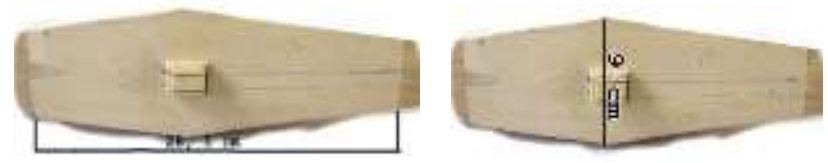

4) Resonator Hole

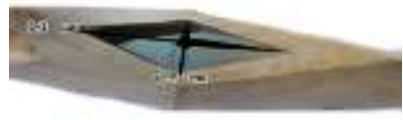

5) Tail Section

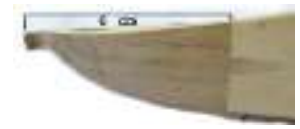

- Kulcapi Game Technique of Karo Society

Traditionally game of kulcapi Karo has been practiced for generations. The appearance of Karo is always associated with the story of the people, namely the story of Tajor's horse. The story of Kuda Si Tajor is a story about the heroism of the people of Karo who have legendary and save the values of local kearipan. The scales system used is the pentatonic scales system. In trying to play the melodies associated with the term Kuda Si Tajor rider, which was stopped with a three-tone tone that always accompanied the rare clatter of Tajor's horse when fighting against colonialism in Karo land in the past. Three tones such as nada mi (3) - sol (5) and la tone (6) are the main characteristics or also as capital in playing melodic patterns of traditional Karo music.

The basic technique in playing kulcapi is to pay attention to the holding position of the kulcapi with the right hand or right fingers holding a sort of picking tool commonly called pick picking both strings once and then by following the rhythmic pattern of traditional music or following the Gungpenganak rhythm pattern. the position of the first string / string is considered to be the bearer while the second string / string is Gung. These patterns are the basic pattern in playing Karo kulcapi.

In the next stage, the fingers of the left hand that were displaced pressed Kulcapi's strings / strings on the neck of Kulcapi played a technique of gill which was creating a distinctive vibration of the sound of the Kulcapi strings. To produce a good rengget technique there are five types of left finger positions. 


\subsection{Formulating the Concept of Organology and Technique Kulcapi Model on Guitar Learning}

In formulating organology concepts and techniques for playing music on guitar learning there are several stages including:

- Conduct an analysis of the need to determine Guitar learning goals

Analysis of the need to determine learning goals is the first step taken to determine what you want after students carry out learning. Learning objectives can be obtained from a series of learning objectives found from needs analysis, from student difficulties in learning practices, from analysis carried out by people who work in fields, or some needs for actual learning.

- The analysis phase of the preparation of the learning material for the game After identifying learning objectives, the next step is to determine the learning material and steps that can be taken to achieve the learning objectives. The final step in the process of analyzing learning objectives is to determine the material skills, knowledge, and attitudes that are called entry behaviors (initial behavior) that are needed by students to begin learning.

- $\quad$ Phase Develop a learning strategy

Learning strategies include; pre-learning activities (pre-activity), presentation of information, practice and feedback (practice and feedback), testing (testing), and following activities. Learning strategies are based on theory and research results, characteristics of learning media used, learning materials and characteristics of students who receive learning. These principles are used to select interactive learning strategy material.

- $\quad$ Phase Compiling assessment instruments

Based on the written learning objectives, learning outcomes need to be evaluated and measured in student learning outcomes. The main emphasis is on the behavioral relationship that is reflected in the learning objectives with what is to do the assessment.

\subsection{Application of Kulcapi Model Perfomance in Guitar Learning}

The application of kulcapi game model on guitar learning is carried out based on the learning design compiled by the lecturer team. In this case the lecturer team first formulated learning objectives which included: 1) providing a fundamental understanding to students about the organological theory of the concept of the instrument, whether it was the structure of the instruments or the techniques of the game. 2) the next goal is to provide understanding to students to be able to explore and develop Kulcapi game techniques on guitar instruments. In applying the kulcapi game model to guitar learning, students (students) were emphasized first to understand well the physical organology of the structure and the traditional techniques of traditional culture in a fundamental way.

In this case the presentation of learning material refers to these two things, namely (organology concepts and physical game techniques). Learning material about the theory and concept of the physical organology was designed to provide reinforcement to students in understanding the basic forms and functions of each part of the musical instrument. Whereas 
the presentation of theory and techniques for playing games emphasizes the practical abilities of students in exploring their game to a better level.

\section{- Kulcapi's organizational learning material includes:}

- The oral history of the cultural traditions of the Kulcapi instruments

- Structure of musical instrument parts of Kulcapi Karo

- Function of the musical instrument parts of Kulcapi Karo

- The tone area of the Kulcapi musical instrument

- Material learning techniques playing kulcapi musical instruments on guitar playing.

- The concept of the karo tradition scales

- The techniques and forms of the Kulcapi melody in the composition of Karo music

- Rengget techniques (Karo traditional musical idioms) in the Kulcapi game

- Explore gibberish techniques in guitar playing

In the process of delivering the organology learning material Kulcapi and learning the techniques of playing the kulcapi which have been compiled into the learning plan carried out for two semesters or one year of learning. With the implementation of a mature strategy, the learning results can be obtained as follows:

Table of analysis of learning outcomes

\begin{tabular}{|c|c|c|c|c|}
\hline No & Learning materials & $\begin{array}{c}\text { odd semester } \\
2017-2018\end{array}$ & $\begin{array}{c}\text { Even semester } \\
2017-2018\end{array}$ & $\begin{array}{l}\text { Achievement level } \\
\text { of understanding } \\
\text { and proficiency }\end{array}$ \\
\hline \multirow[t]{4}{*}{1} & $\begin{array}{l}\text { 1. Oral history of the } \\
\text { cultural traditions of } \\
\text { Kulcapi instruments }\end{array}$ & $\sqrt{ }$ & & $90 \%$ \\
\hline & $\begin{array}{l}\text { 2. Structure of musical } \\
\text { instrument parts of } \\
\text { Kulcapi Karo }\end{array}$ & $\sqrt{ }$ & & $95 \%$ \\
\hline & $\begin{array}{l}\text { 3. Function of the } \\
\text { musical instrument } \\
\text { parts of Kulcapi } \\
\text { Karo }\end{array}$ & $\sqrt{ }$ & & $95 \%$ \\
\hline & $\begin{array}{l}\text { 4. The tone area of the } \\
\text { Kulcapi musical } \\
\text { instrument }\end{array}$ & $\sqrt{ }$ & & $100 \%$ \\
\hline \multirow[t]{2}{*}{2} & $\begin{array}{l}\text { 1. Concept of karo } \\
\text { tradition scales }\end{array}$ & & $\sqrt{ }$ & $100 \%$ \\
\hline & $\begin{array}{l}\text { 2. Technique and form } \\
\text { of Kulcapi melody } \\
\text { in the composition } \\
\text { of karo traditional } \\
\text { music }\end{array}$ & & $\sqrt{ }$ & $95 \%$ \\
\hline
\end{tabular}




\begin{tabular}{|l|l|l|l|}
\hline 3. $\begin{array}{l}\text { Technique of } \\
\text { rengget (idiom Karo } \\
\text { Musical Tradition) } \\
\text { on perfomance } \\
\text { Kulcapi }\end{array}$ & $\sqrt{ }$ & $90 \%$ \\
4. $\begin{array}{l}\text { Explore rengget } \\
\text { techniques in guitar } \\
\text { playing }\end{array}$ & $\sqrt{ }$ & $85 \%$ \\
\hline
\end{tabular}

\section{Conclusion}

\subsection{The issue of how to apply the kulcapi game model to guitar learning is done in stages;}

- Conduct analysis of needs to determine learning objectives

- Conduct analysis of preparation of learning material

- Develop learning strategies

- Develop learning assessment instruments

In applying performance model of Kulcapi Karo as a teaching material in guitar learning students are emphasized students to understand well the basic organology concept of the structure and the traditional techniques of traditional culture. In this case the presentation of learning material refers to these two things, namely (organology concepts and physical game techniques). Learning material about the theory and concept of the physical organology was designed to provide reinforcement to students in understanding the basic forms and functions of each part of the musical instrument. Whereas presentation of theory and techniques for playing games emphasizes the practical abilities of students in exploring their game to a better level.

Implementation of performance model of Kulcapi Karo as a teaching material in guitar learning kulcapi game model designed in two semesters or within one year of learning can show satisfactory results, it can be seen in the table of analysis of learning outcomes which shows the average percentage of learning outcomes above $80 \%$.

\section{References}

Arief, S. Sadiman. 1984. Media Pembelajaran, Pengertian, Pengembangan, Penempatan. Jakarta: Rajawali.

Arikunto, Suharsimi. 2010. Prosedur Penelitian Suatu Pendekatan dan Praktek. Jakarta: Rineka Cipta

April Wright, 2013 Academic and Cognitive trends in Children Living with Autism, California State University, Fullerton Proquest Dissertations Publishing

Blackwood, Alan. 1979. Ward Lock's Encyclopedia Music. London : WARD Lock Limited Bungin, Burhan. 2007. Penelitian Kualitatif. Jakarta : Kencana.

Craft, A. (Ed). (2005). Creativity in Schools Tensions and Dilemmas. New York: Routledge.

Dick and Carry 2010 Model Pembelajaran Dalam Pembelajaran Bahasa Dan Sastra Indonesia 
Fitri Nugra Heni: 2013 : Jurnal - hubungan - motivasi belajar terhadap hasil belajar mahasiswa: (https://www.slideshare.net/SieChachaK/26-des-2013 )

Hornbostel, Erich M. Von and Curt Sach, 1961. Clasification of Musical Instrument. Translate from original German by Anthony Baines and Klausss P.Wachsmann.

Johan, 2013 Psikologi Pendidikan Seni Pusta ilmu Yogyakarta

Leyva, Kylara 2017 Parental Understanding of The Meaning of Autism Spectrum Disorder, JeanThe University of Texas at El Paso, Proquest Dissertations Publishing

Mahmud,2012 Sosiologi Pendidikan Pustaka Setia Bandung.

Moleong, Lexy J. 2010. Edisi: cet.20 Metode Penelitian Kualitatif. Bandung: $\quad$ Remaja Rosdakarya

Merriam, Allan P, 1964. The Antropology of Music. North Western : UniversityPress

Rinehort and Winston. Arsyad, Azhar. 2002.Media Pembelajaran. Jakarta: Raja grafindo Persada.

Rusman, M.Pd. 2010 Model-Model Pembelajaran, Mengembangkan Profesional

Sadiman. 1984. Media Pendidilkan Pengertian, Pengembangan dan Pemanfaatan. Jakarta: CV. Raja Wali.

Sadiman, Arif, dkk. 2002. Media Pendidikan, Pengertian, Pengembangan, dan Pemanfaatan (edisipertama, cetakan ke-10). Jakarta: PT. Raja Grafindo Persada.

Sanjaya, wina. (2008). Strategi Pembelajaran Berorientasi Standar Proses Pendidikan. Jakarta : Kencana Prenada Media Group.

Sitepu Beri Pana, 2013. Kajian Organologi Kulcapi Pada Masyarakat Karo Buatan Bapak Pauji Ginting Skripsi Sarjana Departemen Etnomusikologi Fakultas Ilmu Budaya Universitas Sumatera Utara.

Sugiyono,2013. Metode Penelitian Kuantitatif, Kualitatif dan R\&D.Bandung : Alfabet. 